\title{
O processo de ensino-aprendizagem de português escrito para surdos em sessões de tandem
}

\author{
Quintino Martins de Oliveira ${ }^{1}$ \\ Francisco José Quaresma de Figueiredo ${ }^{2}$ \\ Faculdade de Letras, Programa de Pós-Graduação em Letras e Linguística, \\ Universidade Federal de Goiás, Goiânia, GO, Brasil
}

Resumo: Este artigo tem por objetivos analisar as interações entre alunos surdos e ouvintes, verificar que estratégias os ouvintes usaram para auxiliar a aprendizagem de português escrito pelos surdos, durante sessões de tandem face a face, bem como obter as percepções dos surdos acerca de sua participação nessas sessões. Trata-se de uma pesquisa qualitativa, e os dados foram coletados em três sessões de tandem, no primeiro semestre de 2017, por meio de gravações em vídeo dessas sessões, bem como de entrevistas realizadas com os participantes surdos. Os resultados indicam que as interações possibilitaram aos surdos aprender português escrito de forma eficaz quando os ouvintes usavam recursos visuais que facilitaram esse processo. Em contrapartida, o uso de oralização e de gestos, por parte dos ouvintes, durante as interações, dificultou a aprendizagem dos surdos. Concluímos que a abordagem em tandem, muito utilizada com línguas orais, é também favorável no ensino-aprendizagem de português escrito para surdos.

Palavras-chave: Aprendizagem colaborativa; Português para surdos; Ensino-aprendizagem da escrita; Português escrito; Aprendizagem de línguas em tandem.

Title: The teaching-learning process of written Portuguese for the deaf in tandem sessions

Abstract: This paper aims to analyze the interactions between hearing and deaf students, to verify the strategies the hearing participants used to assist the learning of written Portuguese by the deaf, during face-to-face tandem sessions, as well as to obtain the perceptions of the deaf about their participation in these sessions. It is a qualitative research method, and the data were collected in three tandem sessions, in the first half of 2017, through video recordings of these sessions, as well as interviews with the deaf participants. The results indicate that the interactions enabled the deaf participants to learn written Portuguese effectively when the hearing participants used visual aids that facilitated this process. In contrast, the use of oralization and gestures by the hearing participants, when communicating with the deaf, made this process difficult. We conclude that the tandem approach, widely used with oral languages, is also favorable in the teaching-learning process of Portuguese for the deaf.

Keywords: Collaborative learning; Portuguese for the deaf; Teaching/learning of writing; Written Portuguese; Tandem language learning.

\footnotetext{
${ }^{1}$ Mestre e Doutorando em Letras e Linguística pela UFG. Docente do Departamento de Libras e Tradução da Faculdade de Letras/UFG. Orcid: https://orcid.org/0000-0001-5441-0062. E-mail: quintino oliveira@ufg.br.

2 Doutor em Linguística Aplicada pela UFMG, tendo realizado estágio pós-doutoral na mesma Instituição. Docente do Departamento de Línguas Estrangeiras e do Programa de Pós-Graduação em Letras e Linguística da Faculdade de Letras/UFG. Orcid: https://orcid.org/0000-0002-5936-1578. E-mail: franciscofigueiredo@ufg.br.
} 


\section{Introdução}

Por um longo período, o surdo foi visto por uma perspectiva clínica que o considerava como defeituoso e que deveria ser "reparado" por intermédio de técnicas fonoaudiológicas que pudessem "consertar" esse sujeito e desenvolver nele a fala oral ${ }^{3}$ para que ele pudesse adquirir uma língua (SKLIAR, 2015). Conforme nos esclarece Quadros (2017), por sermos ideológica e historicamente reconhecidos como um país monolíngue em língua portuguesa, a difusão e o uso da língua brasileira de sinais (Libras) acabavam ficando restritos principalmente a espaços informais em que a comunidade surda se fazia presente.

Novas políticas linguísticas educacionais, voltadas à comunidade surda, começaram a se estruturar e, assim, um novo cenário linguístico surge em contextos educacionais inclusivos. Nesse sentido, surdos e ouvintes passaram a compartilhar o mesmo espaço físico, - que poderia viabilizar-Ihes trocas linguísticas e culturais (OLIVEIRA, 2017). Essa convivência, no entanto, desafia o fluir natural das interações entre surdos e ouvintes, pois, em sua maioria, os surdos não possuem grande conhecimento da língua portuguesa, e os ouvintes, em geral, não sabem Libras.

Além do mais, essas políticas inclusivas educacionais não atendem às características biológicas e socioculturais do aluno surdo, pois não envolvem essas questões no currículo escolar (CALIXTO; RIBEIRO; RIBEIRO, 2019). Assim, geralmente, na escola, não são contempladas discussões culturais e identitárias do surdo, o ensino de português para surdos como segunda língua ${ }^{4}$ na modalidade escrita, e a difusão e a valorização da Libras. Em geral, faltam, ainda, conhecimento e uso de recursos visuais didáticos pelos professores, bem como há carência de profissionais intérpretes, entre outras questões (LIMA, 2012). Esses fatores podem influenciar os índices de desistência e de fracasso escolar dos estudantes surdos (FERNANDES, E., 2003; SILVA, 2001), pois, conforme vêm mostrando diversos estudos, essas questões precisam ser contempladas para viabilizar aos surdos, juntamente com seus colegas ouvintes, um processo de ensino-aprendizagem eficiente (veja, por exemplo, FELIPE, 2006; FERNANDES, E., 2003; GÓES, 1999; LACERDA; LODI, 2009; QUADROS; FINGER, 2008, entre outros).

É nessa diversidade linguística, possibilitada pela educação inclusiva - surdos estudando com ouvintes -, que se encontra um terreno fértil para a realização de pesquisas sobre a importância da interação também em contextos de aprendizagem de línguas para surdos (FIGUEIREDO; OLIVEIRA-SILVA, 2016; OLIVEIRA, 2017; LACERDA; LODI, 2009; PEREIRA, 2014; RIBEIRO, 2013; SILVA, 2001). Tais pesquisas contribuem para um novo pensar

\footnotetext{
${ }^{3}$ Usamos o termo 'fala oral' para designar a produção de língua através do aparelho fonador dos falantes de línguas orais. $\mathrm{O}$ oralismo foi uma abordagem educacional, desenvolvida para os surdos, que consistia no uso de técnicas fonoaudiológicas, como, por exemplo, a leitura labial, para desenvolver neles a fala oral. Para mais informações, veja Oliveira e Figueiredo (2017a).

${ }^{4}$ De acordo com Figueiredo (2015), o termo 'segunda língua' (L2) se refere à língua que é aprendida na escola e que se difere da língua materna (L1 ou LM) do indivíduo. No Brasil, o português é considerado segunda língua para os surdos e para a maioria dos indígenas, que não têm o português como sua L1 (FIGUEIREDO; OSÓRIO; MIRANDA, 2016).
} 
pedagógico para o processo educacional do surdo, e, neste estudo, trazemos mais uma contribuição: a aprendizagem em contexto de tandem face a face - uma abordagem de ensino-aprendizagem em que duas pessoas de línguas diferentes, geralmente falantes de línguas orais, se reúnem, em um mesmo espaço físico para ensinar a seu parceiro a língua de que são nativos ou em que são proficientes (BENEDETTI; RODRIGUES, 2010; BRAMMERTS, 2002; FIGUEIREDO; SILVA, 2016).

De acordo com o Webster's Encyclopedic Unabridged Dictionary of the English Language, a palavra tandem, em inglês, significa "algo ou alguém em frente ou atrás de outro" ${ }^{5}$ linearmente, ou "em associação ou parceria ${ }^{6 "}$. Esse termo7 é também usado para se referir à bicicleta que possui dois ou mais assentos (tandem bicycle), um em frente ao outro. Em uma perspectiva educacional, o termo é usado metaforicamente para designar o esforço mútuo entre duas ou mais pessoas que trabalham juntas para realizar uma tarefa, como, por exemplo, quando duas pessoas ou mais pedalam a mesma bicicleta, refletindo, assim, o conceito de colaboração (BRUFFEE, 1999; FIGUEIREDO, 2018, 2019; SOUZA, 2003, 2006). Dessa forma, quando dizemos que os aprendizes trabalham em tandem, queremos dizer que trabalham juntos, em parceria.

Poucos são os estudos publicados no Brasil sobre a aprendizagem em tandem que têm como par linguístico uma língua oral (português) e uma língua sinalizada (Libras) (cf. OLIVEIRA; FIGUEIREDO, 2017b; FIGUEIREDO; OLIVEIRA, 2019). Assim, esta pesquisa pretende colaborar para uma maior compreensão do assunto, enfocando o processo de ensinoaprendizagem de português escrito para estudantes surdos em sessões de tandem face a face, com os seus parceiros ouvintes.

Além desta parte introdutória, este artigo está dividido em mais quatro seções. $\mathrm{Na}$ primeira seção, discutimos alguns pressupostos teóricos referentes ao processo de ensinoaprendizagem de português escrito para surdos, bem como à abordagem colaborativa de línguas ${ }^{8}$, em contexto de tandem face a face. Na segunda, explicitamos os aspectos metodológicos utilizados para a geração dos dados. Na terceira, apresentamos a análise dos dados que se divide em dois tópicos: a) análise das interações e recursos usados nas sessões de tandem durante o ensino de português aos surdos; e b) análise das percepções dos surdos sobre sua participação nessas sessões. Na quarta e última parte, apresentamos algumas considerações finais por meio de reflexões sobre os resultados das análises e sobre o uso do processo de ensino-aprendizagem em tandem com o par linguístico

\footnotetext{
${ }^{5}$ Nossa tradução de: "one following or behind the other" (WEBSTER, 1989, p. 1452, Def. 1).

${ }^{6}$ Nossa tradução de: "in association or partnership" (WEBSTER, 1989, p. 1452, Def 2.b).

${ }^{7}$ Tandem também é usado em estudos das línguas de sinais para se referir ao sinal que é produzido em que uma mão está na frente da outra (KIM; LIVESCU; SHAKHNAROVICH, 2012). Como exemplo, podemos mencionar o sinal /ENCONTRAR/ em Libras, em que, ao produzi-lo, colocamos uma mão em frente à outra (CAPOVILLA; RAPHAEL; MAURÍCIO, 2013, p. 1064).

${ }^{8} \mathrm{~A}$ abordagem ou aprendizagem colaborativa de línguas refere-se a "situações educacionais em que duas ou mais pessoas aprendem ou tentam aprender algo juntas", em contextos presenciais e virtuais (FIGUEIREDO, 2018, p. 14), levando-os a um processo de coconstrução da aprendizagem (BRUFFEE, 1999; NUNAN, 1992; OXFORD, 1997; SOUZA, 2003; SWAIN, 2000, entre outros).
} 
Libras/português. Passemos, então, à primeira parte, em que apresentamos o referencial teórico para este estudo.

\section{0 ensino-aprendizagem de português para surdos: foco na abordagem colaborativa de línguas, em contexto de tandem face a face}

Como mencionado na introdução deste estudo, numa perspectiva histórica acreditava-se que o uso da oralização (Oralismo) era a única possibilidade para o surdo adquirir língua (BOTELHO, 2013; SKLIAR, 2015) e, como vimos, essa metodologia não foi bem-sucedida. Assim, surgiu a Comunicação Total - uma corrente pedagógica que aliava diferentes metodologias e estratégias para o ensino da língua oral aos surdos. Essa

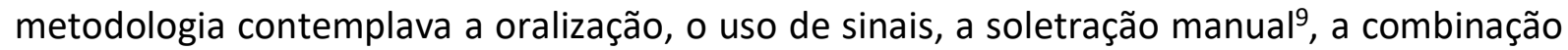
desses modos, ou mesmo outros meios como o uso de técnicas e recursos voltados para a estimulação auditiva, adaptação de aparelho de amplificação sonora individual e leitura labial (CICCONE, 1990; OLIVEIRA; FIGUEIREDO, 2017a).

Dessa forma, o uso da língua de sinais era percebido apenas como um recurso no processo de ensino da língua oral, e não como língua natural dos surdos (CICCONE, 1990; GOLDFELD, 1997; RABELO, 1992). Assim, essa metodologia continuava a desconsiderar os aspectos linguísticos naturais da língua de sinais e a estruturava com base nas relações gramaticais das línguas orais; ou seja, os profissionais da educação de surdos à época utilizavam o léxico da língua de sinais submetido à gramática das línguas orais (GOLDFELD, 1997).

Para os estudiosos da Comunicação Total, a única forma de assegurar uma interação comunicativa eficaz, capaz de promover o desenvolvimento da linguagem nos surdos, era por meio de estratégias que levassem ao uso simultâneo da oralização e do português sinalizado ${ }^{10}$, processo esse definido como bimodalismo (BOTELHO, 2013; CICCONE, 1990; GOLDFELD, 1997; RABELO, 1992).

No entanto, Botelho (2013, p. 122) nos chama a atenção para o fato de que o bimodalismo não é eficaz, por razões linguísticas, visto que,

[a]lém de dificultar a estruturação do pensamento, já que com a busca constante de ajuste entre fala e sinais perde-se o fio condutor do assunto, a simultaneidade veiculada pelo bimodalismo deforma a enunciação, que se torna uma montagem artificial, e sempre baseada na língua oral.

Desse modo, as metodologias do Oralismo e da Comunicação Total não atingiram seu objetivo - levar o surdo a adquirir a língua oral de uma forma natural -, pois, conforme reconhecem vários autores, a aquisição do português escrito pelo surdo é um processo

\footnotetext{
${ }^{9}$ Soletração manual, ou datilologia, é um conjunto de configurações de mão que representa o alfabeto em português por meio da soletração das letras (QUADROS; KARNOPP, 2004).

10 Português sinalizado é o uso dos léxicos da língua de sinais brasileira na estrutura da língua portuguesa, privilegiando, assim, a sintaxe linear da língua oral, desconsiderando a sintaxe visuoespacial das línguas de sinais (BOTELHO, 2013; QUADROS, 1997).
} 
diferente do experienciado pelos ouvintes (ALMEIDA; LACERDA, 2019; FERNANDES, E., 2003; FERNANDES, S. F., 2003; LODI; BORTOLOTTI; CAVALMORETI, 2004). Ou seja, enquanto o ouvinte "reconstrói a história de sua relação com a linguagem por meio da língua oral, o surdo percorre tal caminho orientando-se pela língua de sinais" (ALMEIDA; LACERDA, 2019, p. 900).

Lodi, Bortolotti e Cavalmoretti (2014, p. 136) afirmam que se torna "importante considerar também que muitos adultos surdos sofreram um processo de escolarização que buscava sua normalização pela linguagem oral da língua portuguesa", por meio de técnicas de oralização, que, em geral, não se mostraram bem-sucedidas. Assim, para favorecer o processo de aprendizagem do português para os surdos, o professor pode, por meio da interação (VYGOTSKY, 1998), discutir a estrutura da Libras e compará-la à estrutura do português. Para tanto, o professor pode usar algumas estratégias de ensino, que são definidas como técnicas ou ferramentas facilitadoras da aprendizagem, utilizadas com o objetivo de ajudar o outro a construir conhecimentos, com base em suas vivências e especificidades, bem como em seus conhecimentos prévios (ANASTASIOU; ALVES, 2004; BORDENAVE; PEREIRA, 1998; FIGUEIREDO; OLIVEIRA-SILVA, 2016).

Segundo Fernandes, E. (2003) e Figueiredo e Oliveira-Silva (2016), os professores, ao ensinar a pessoas surdas, precisam usar recursos visuais, como, por exemplo, desenhar no quadro branco, usar objetos e imagens, destacar palavras-chave, usar símbolos como circular palavras ou usar setas para ligar palavras a imagens, usar cores diferentes de pincéis para escrever no quadro branco, grifar palavras etc. A aplicação desses recursos, mediada na interação pela língua de sinais, configura-se como estratégias de ensino eficazes, visto que pistas sonoras, muito utilizadas no processo de ensino-aprendizagem da leitura e da escrita para ouvintes, se mostram ineficazes aos surdos. Ou seja, a palavra é percebida por sua propriedade visual (ortografia) e não por estímulos auditivos.

Em contextos de educação inclusiva, uma das possibilidades de favorecer a interação no processo de ensino-aprendizagem de Libras, por ouvintes, e de português como segunda língua, na modalidade escrita, pelos surdos, é a utilização de uma abordagem colaborativa conhecida por aprendizagem em contexto de tandem. Trata-se de um processo de trocas linguísticas e culturais entre indivíduos que possuem línguas diferentes e que se propõem a ajudar o outro a aprender a sua língua, de modo colaborativo (BENEDETTI; RODRIGUES, 2010; BRAMMERTS, 2002; GARCIA, 2013; VASSALLO; TELLES, 2009).

Em sessões de tandem, as interações dos aprendizes devem obedecer a alguns princípios, como: a) sociabilidade simétrica - há uma mudança alternada de papéis entre quem ensina e quem aprende; b) interpessoalidade - a interação se estabelece entre pares de aprendizes; c) reciprocidade - cada aprendiz deve auxiliar o seu parceiro na aprendizagem de línguas, ofertando e recebendo ajuda; d) separação das línguas - deve haver o uso alternado e equilibrado das línguas que estão sendo aprendidas, sendo cada língua o foco de uma sessão; e) autonomia - os parceiros podem escolher o que desejam aprender na língua do outro - já que não há um currículo fixo de conteúdo a ser ministrado 
-, e, assim, tornam-se responsáveis pela própria aprendizagem (BRAMMERTS, 2002; VASSALO; TELLES, 2009).

Durante as interações em tandem, os aprendizes podem ajudar uns aos outros por meio da oferta de scaffoldings. Trata-se de um termo cunhado por Wood, Bruner e Ross (1976), traduzido por 'andaime' ou 'andaimento' em português (FIGUEIREDO, 2018, 2019) que se refere a instruções dadas ao aprendiz pelo professor ou por parceiros mais experientes, "como apoio temporário para que os aprendizes obtenham progressivamente compreensão sobre como realizar determinada tarefa e possam, posteriormente, realizá-la de forma independente" (FIGUEIREDO, 2019, p. 52). Ainda, de acordo com Figueiredo (2019), podemos prover scaffoldings por meio do uso de vários recursos como vídeos, diagramas, desenhos, objetos etc., e ele pode ocorrer por meio de perguntas, demonstrações, instruções ou modelos que sirvam de orientação para que, durante a interação, a tarefa se realize.

Com base no exposto, o objetivo deste estudo é verificar quais estratégias usadas pelos ouvintes - para auxiliar o processo de ensino-aprendizagem de português escrito para surdos, durante sessões de tandem face a face - foram consideradas por estes como eficazes ou não para esse processo, bem como apresentar suas percepções acerca de sua participação nessas sessões.

\section{Metodologia do estudo}

Esta pesquisa qualitativa (BOGDAN; BIKLEN, 1994) foi realizada na Universidade Federal de Goiás (UFG) com a participação de dois pares de estudantes surdos e ouvintes, maiores de idade, do 30 período do curso de Letras: Libras ${ }^{11}$, que se voluntariaram para participar de seis sessões de tandem e de entrevistas ${ }^{12}$. Foram três sessões destinadas ao ensino de Libras, e três, ao ensino de português. Selecionamos alunos dessa turma, pois os alunos ouvintes já teriam algum conhecimento de Libras, e, por sua vez, os alunos surdos já teriam estudado português escrito em seu curso de graduação. Ao definir como participantes deste estudo alunos em processo de formação de professores de Libras, pudemos viabilizar-Ihes reflexões sobre o processo de ensino-aprendizagem de uma L2.

Os participantes deste estudo foram identificados por pseudônimos escolhidos por eles, a saber: Cristal (ouvinte) e Bruna (surda); Saskya (ouvinte) e Felipe (surdo). Neste artigo, focaremos apenas no processo de ensino-aprendizagem dos participantes surdos.

O estudo foi aprovado pelo Comitê de Ética em Pesquisa (CEP) da UFG ${ }^{13}$ e foi realizado em uma sala da Faculdade de Letras $(F L)^{14}$ da UFG no período vespertino, durante

\footnotetext{
${ }^{11}$ O curso de Letras: Libras da UFG foi o primeiro curso a ser ofertado na modalidade presencial no Brasil, sendo criado em 2009.

12 Foram realizadas uma entrevista inicial com os quatro participantes, uma entrevista individual ao final de cada sessão de tandem, e uma entrevista individual ao final de todo o processo.

13 Parecer no. 1.955.477, do CEP/UFG, emitido em 9 de março de 2017.
} 
o primeiro semestre de 2017, com duas horas de duração cada uma, sendo um encontro por semana. As sessões foram realizadas em uma sala reservada para esse fim, para que os alunos que desejassem participar do estudo pudessem fazê-lo sem prejudicar o atendimento ao curso. Durante as sessões, estavam presentes um aluno surdo e um ouvinte, bem como o primeiro autor deste artigo, que atuou como observador não participante. As sessões de cada dupla foram gravadas em dias diferentes. Como, neste estudo, contamos com a participação de estudantes surdos, as sessões de tandem e as entrevistas foram realizadas em Libras, gravadas em vídeo e, posteriormente, traduzidas para o português. Fotografamos também tudo que era escrito no quadro branco, bem como as imagens e os objetos levados para as sessões.

As temáticas das sessões foram: "partes da casa" (1a sessão), "profissões" (2a sessão) e "estados brasileiros" (3a sessão) ${ }^{15}$. À época da coleta dos dados, essas temáticas contemplavam o conteúdo curricular da disciplina de Libras que seria trabalhado no semestre posterior e, assim, os alunos ainda não o haviam estudado.

\section{Análise dos dados}

Após o período de coleta de dados, iniciamos o processo de análise que se dividiu em dois temas que nos auxiliaram na compreensão do processo de ensino-aprendizagem de português escrito para os alunos surdos: a) análise das interações ocorridas entre estudantes surdos e ouvintes nas sessões de tandem face a face e das estratégias usadas pelos ouvintes durante o processo de ensino-aprendizagem de português escrito; e b) análise das percepções dos alunos surdos acerca de sua participação nas sessões de tandem face a face.

Análise das interações ocorridas entre estudantes surdos e ouvintes nas sessões de tandem face a face e as estratégias usadas pelos ouvintes durante o processo de ensinoaprendizagem de português escrito

Durante as interações, uma das estratégias usadas pelos ouvintes para auxiliar os parceiros surdos no processo de ensino-aprendizagem de português escrito foi o uso da soletração manual (datilologia), acompanhado de scaffoldings que levaram o surdo à compreensão da palavra. No exemplo a seguir, sobre o tema 'profissões', Saskya relembra a Felipe que, durante a sessão anterior, em que ele ensinou a ela profissões em Libras, ambos comentaram que têm parentes que são médicos. Ela resgata essa interação para iniciar a sessão com o objetivo de ensinar a Felipe a palavra 'cirurgião' em português. Ela inicia sua narrativa em Libras dizendo que seu pai é 'cirurgião' e, nesse momento, como

\footnotetext{
${ }^{14}$ A FL sedia o curso de Letras: Libras, que é ofertado no período noturno, e tem por objetivo formar professores de Libras.

${ }^{15}$ Nas análises, utilizamos apenas dados das 1a e $2^{2}$ sessões, visto que, na 3a sessão (estados brasileiros), não houve o uso de estratégias diferentes.
} 
desconhece o sinal equivalente a essa palavra, ela a oraliza, mas Felipe não compreende o que ela quer dizer por meio do movimento dos lábios. Desse modo, ela soletra manualmente 'C-I-R-U-R-G-I-Ã-O' e constrói, com Felipe, o seu significado a partir do conceito de 'cirurgia' em Libras, fazendo-o compreender a palavra 'cirurgião'. Vejamos a interação.

[1]

Saskya: Boa tarde! Tudo bem? Você lembra que você me ensinou o sinal de 'médico', e eu te falei que meus pais são médicos?

Felipe: $\quad$ Sim, eu me lembro. Eu contei que meu primo também é médico, lembra?

Saskya: $\quad$ Sim, eu me lembro. Então, agora eu quero te explicar a especialidade do meu pai. Ele é 'cirurgião' [Saskya oraliza a palavra 'cirurgião'].

Felipe: $\quad$ Não entendi. É o que? [Felipe faz expressão facial de quem não entende algo e balança a cabeça em negação].

Saskya: $\quad$ C-I-R-U-R-G-I-Ã-O. [Saskya faz uso da soletração manual]. Conhece?

Felipe: $\quad$ Não, essa palavra eu não conheço. Eu conheço a palavra C-I-R-U-R-G-I-A [Felipe faz uso da soletração manual]. É igual?

Saskya: $\quad$ Ok. A palavra C-I-R-U-R-G-I-A [Saskya faz uso da soletração manual] significa, por exemplo, uma pessoa que foi ao hospital e fez C-I-R-U-R-G-I-A [Saskya faz uso da soletração manual] na barriga, ou no braço, ou em qualquer lugar do corpo, certo?

Felipe: $\quad$ Sim. Exato. Vai ao hospital, e lá eles levam para uma sala e faz C-I-R-U-R-G-I-A [Felipe faz uso da soletração manual para 'cirurgia' e simula alguém sendo levado em uma maca para uma sala de cirurgia].

Felipe: $\quad$ Posso falar uma coisa?

Saskya: $\quad$ Claro! O que é?

Felipe: $\quad$ Em Libras, C-I-R-U-R-G-I-A [Felipe faz uso da soletração manual] é assim [faz o sinal de 'cirurgia' simulando uma tesoura na mão cortando e abrindo a barriga].

Saskya: $\quad$ Ah, sim, que legal. Ok. Então, quem faz a cirurgia? [Saskya reproduz o sinal que Felipe ensinou simulando uma tesoura na mão cortando e abrindo a barriga].

Felipe: $\quad$ O médico? [Felipe faz uso de expressão facial para dúvida].

Saskya: $\quad$ Sim, mas qualquer médico pode fazer cirurgia? [Saskya repete o sinal de 'cirurgia' que aprendeu com Felipe].

Felipe: $\quad$ Acho que não, porque tem médico próprio para cada coisa, por exemplo, médico do ouvido, médico da cabeça, médico do coração. Acho que cirurgia também tem um médico específico, certo? Eu acho [risos].

Saskya: Você quase acertou [risos]. Cada médico que você explicou para mim: médico do ouvido, médico da cabeça, médico do coração pode ou não ser um C-I-R-U-R-G-I-Ã-O [Saskya faz uso da soletração manual]. Ele precisa estudar profundamente muitos anos e praticar muitas C-I-R-U-RG-I-A-S [faz uso da soletração manual].

Felipe: $\quad$ Ah, sim. Entendi agora. Então C-I-R-U-R-G-I-Ã-O [Felipe faz uso da soletração manual] é o nome do médico que faz cirurgia, certo?

Saskya: Exato! Agora você entendeu. Muito bom... Então, meu pai é C-I-R-U-R-G-I-Ã-O [Saskya faz uso da soletração manual]. Ele faz cirurgia em muitas pessoas [reproduz o sinal de 'cirurgia' que aprendeu com Felipe].

Felipe: $\quad$ Ah, sim. Entendi agora. Eu pensava que todos os médicos faziam cirurgias. Nossa, que legal! Eu acho que nunca seria um C-I-R-U-R-G-I-Ã-O [Felipe faz uso da soletração manual] porque não gosto de sangue [risos].

Saskya: Eu também não gosto de sangue [risos]. Por isso, nós dois estamos aqui no Letras: Libras, né? [risos].

Felipe: $\quad$ É verdade [risos]. Melhor ser professor de Libras [risos].

(Fonte: Sessão de tandem face a face sobre 'profissões', em que Felipe aprende português com Saskya). 
O uso da soletração manual de uma palavra, acrescido de scaffoldings que levam à compreensão da palavra (como, por exemplo, explicações e exemplos), é considerado como uma estratégia eficaz, usada nas interações colaborativas neste estudo. Entretanto, apenas o uso da soletração manual pode não ser eficaz todas as vezes (QUADROS; KARNOPP, 2004), pois vai depender do conhecimento prévio do surdo de palavras na língua portuguesa e do auxílio que recebe para compreender o conceito que the é ensinado. Alguns autores também salientam que o uso da soletração manual como um recurso comunicativo pode bloquear o fluxo natural da interação, dificultando a estruturação do pensamento do surdo, por fazer com que ele fique em um processo constante de mudança de código (português e Libras) (BOTELHO, 2013; CICCONE, 1990; GOLDFELD, 1997; RABELO, 1992).

Conforme percebemos no exemplo [1], Saskya primeiramente utiliza a estratégia de oralizar e da soletração manual para introduzir o conceito de 'cirurgião'. Porém, nesse momento da interação, percebemos que tanto o uso da oralização quanto o uso da soletração manual não conseguiram vincular o significado da palavra (BOTELHO, 2013; OLIVEIRA, 2017), devido ao fato de ela ser desconhecida por Felipe.

Nessa interação, podemos perceber que Felipe, ao dizer que desconhece a palavra 'cirurgião', mas conhece a palavra 'cirurgia', nos evidencia que a palavra em português, para o surdo, tem um valor imagético. Ou seja, 'cirurgia' é uma imagem, e 'cirurgião' é outra e, por isso, Felipe não relaciona as palavras, conforme é comum aos ouvintes assim fazê-lo pelo apoio sonoro (ALMEIDA; LACERDA, 2019).

Saskya, por meio dessa interação, conseguiu ampliar o vocabulário na língua portuguesa de Felipe, bem como fazê-lo compreender que os especialistas que ele conhecia (médico de ouvido, médico do coração etc.) não são automaticamente cirurgiões. Apesar de ser uma sessão destinada ao ensino-aprendizagem do português, ela também pôde aprender com seu parceiro surdo o sinal de 'cirurgia', pois, em sessões de tandem, é difícil aos participantes focar em apenas uma das línguas envolvidas na interação (FIGUEIREDO; SILVA, 2016).

A estratégia de oralizar foi um recurso muito frequente usado pelos participantes ouvintes ao ensinar português aos colegas surdos. Ela foi acompanhada do uso simultâneo da fala com o uso de gestos. Ocorre que, em diversos momentos, a fala se tornava confusa aos participantes surdos, mesmo quando o ouvinte falava mais lentamente, como ilustra o exemplo a seguir em que Cristal está ensinando 'partes da casa' em português e faz o uso da oralização acompanhada de gestos para designar o conceito de 'móveis'. Vejamos.

[2]

Cristal: Na sua casa tem muitos 'móveis' [Cristal oraliza a palavra 'móveis' e faz o uso de gestos com a mão aberta no espaço como se estivesse apontando para vários móveis].

Bruna: $\quad$ Não entendi. Você tá falando o quê? O que significa M-O-V [Bruna faz uso da soletração manual]. Cristal: M-O-V [Cristal faz uso da soletração manual] não. M-Ó-V-E-I-S [Cristal faz uso da soletração manual]. 
A oralização e o uso de gestos, em algumas interações, evidenciam-se como uma estratégia que dificulta a aprendizagem de português pelos surdos. Como pudemos verificar, Cristal, ao oralizar e usar gestos, não conseguiu auxiliar Bruna em seu processo de aprendizagem de português. A esse respeito, Botelho (2013) e Figueiredo e Oliveira-Silva (2016) postulam que a oralização em si, sem o uso de outros aportes didáticos visuais (como imagens ou escrita), pode prejudicar a aprendizagem da língua portuguesa para os surdos, tal como ocorreu na interação entre Cristal e Bruna.

Entretanto, por estarem as participantes em um ambiente colaborativo de aprendizagem (BRUFFEE, 1999; FIGUEIREDO, 2018, 2019), Bruna pede à colega ouvinte que, em vez de oralizar, escreva no quadro a palavra a Ihe ser ensinada. Essa solicitação de Bruna demonstra que, na colaboração, mesmo o uso inadequado de uma estratégia pode desencadear o uso de outros recursos mediadores da aprendizagem. Vejamos a interação.

[3]

Bruna: $\quad$ Espere um pouco... Posso falar uma coisa para te ajudar?

Cristal: $\quad$ Pode.

Bruna: Não oraliza não! Eu não entendo claramente os movimentos de seus lábios. Melhor você escrever no quadro. Se eu te entender, eu te ajudo mostrando os sinais e, assim, você consegue me ensinar português, ok?

Cristal: $\quad$ Ah, sim. Desculpa, te entendi. Eu sei pouco Libras, fico insegura, mas você me ajuda e eu vou conseguir. Tá bom, vou escrever no quadro.

Pesquisador: Cristal vai ao quadro e escreve a palavra 'móveis'.

(Fonte: Interação na sessão sobre 'partes da casa' em português).

Conforme podemos perceber na interação entre Bruna e Cristal, as estudantes se propõem a se ajudar mutuamente durante a interação entre elas, coconstruindo conhecimentos (FIGUEIREDO, 2018, 2019; VYGOTSKY, 1998). Essa construção colaborativa só foi possível a partir do momento em que Bruna esclarece que o uso da oralização é uma estratégia ineficaz e propõe à Cristal o uso da escrita da palavra no quadro, o que é prontamente atendido por ela, como podemos ver na seguinte figura.

Figura 1 - Escrita do vocábulo 'móveis' feita por Cristal no quadro

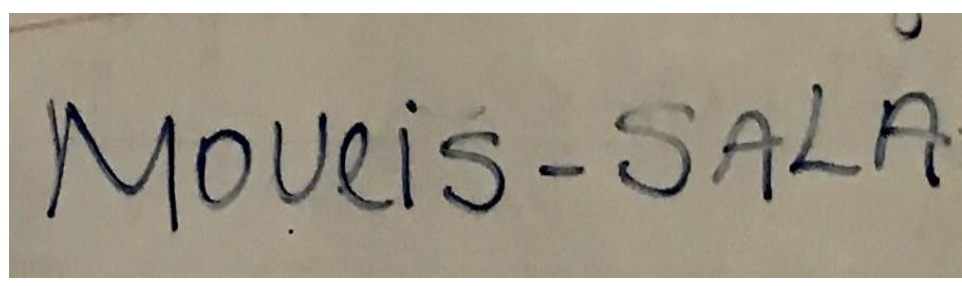

Fonte: Sessão sobre 'partes da casa' em português.

Para ensinar vocabulário relativo a mobiliário, Cristal também levou, para a sessão de tandem face a face, uma sala de estar de brinquedo, com os nomes dos móveis e objetos escritos em português anexados a eles, conforme podemos observar na figura 2. 
Figura 2 - Objetos da sala de estar de brinquedos levados por Cristal

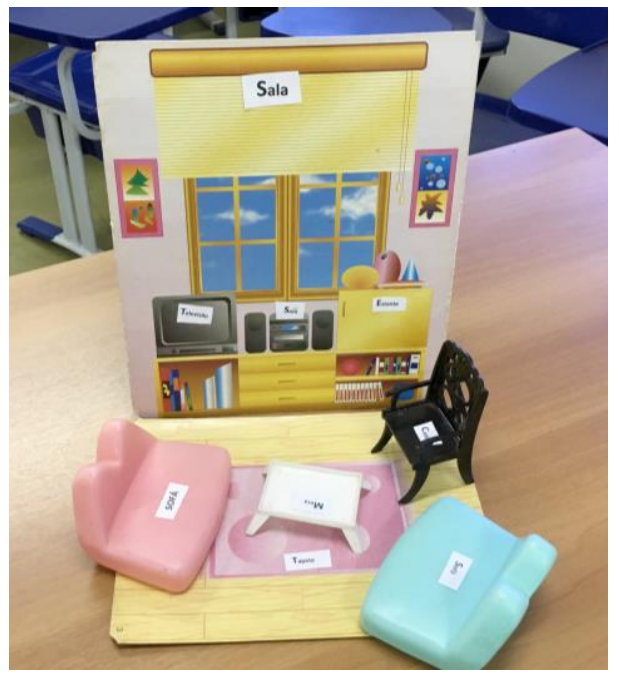

Fonte: Sessão sobre 'partes da casa' em português.

Cristal retoma a sessão montando, na mesa da sala de aula, a sala de estar de brinquedos. Ela vai ao quadro branco, escreve as palavras 'Móveis' e 'Sala', aponta para os objetos e inicia a interação. Aqui, observamos a integração da estratégia da escrita no quadro branco, recurso solicitado por Cristal, à prática de ensino de Bruna. Esse fator revela a reciprocidade entre o par, o respeito ao processo de aprender do outro, e, principalmente, a sintonia entre as participantes na coconstrução da aprendizagem em tandem (BRAMMERTS, 2002; VASSALLO; TELLES, 2009). O uso de objetos e da escrita no quadro configura-se também como uma estratégia de ensino eficaz, como apontado por Fernandes, E. (2003) e Figueiredo e Oliveira-Silva (2016). Vejamos a interação no recorte 4.

[4]

Cristal: Qual o sinal? [Cristal aponta para os móveis].

Bruna: $\quad$ 'Objeto', 'diversos'.

Cristal: Sinal 'objeto' [Cristal começa a repetir o sinal de 'objeto', quando Bruna a interrompe].

Bruna: Precisa fazer o sinal de 'objeto', mas precisa também fazer o sinal de 'sofá', 'televisão', 'mesa' e 'diversos'. Se fizer assim, os surdos irão entender que o 'objeto' refere-se a esta palavra [Bruna aponta para a palavra 'móveis', escrita no quadro, e explica que, para o surdo entender o conceito de 'móveis', é necessário apontar para vários móveis ao mesmo tempo].

[Cristal balança a cabeça em sinal de concordância, repete o sinal de 'objeto' e 'sofá' e começa a fazer o sinal de 'quadrado', quando Bruna a interrompe novamente].

Bruna: Não! Você precisa fazer todos os sinais: 'sofá', 'televisão', 'mesa' e 'diversos'. Não pode fazer só 'sofá' porque fica confuso para o surdo que está vendo sua sinalização entender o que você está dizendo.

Cristal: [Cristal sorri, balança a cabeça, concordando com a colega, e reproduz os sinais de 'mesa' e 'sofá', apontando para a palavra 'sala']. 'Quadrado' significa S-A-L-A [Cristal faz uso da soletração manual] 'sofá' e 'mesa' são M-O-V-E-I-S [Cristal faz uso da soletração manual].

Bruna: Entendi. M-O-V-I-L [Bruna faz uso da soletração manual]. Não, M-O-V-E-I-S [Bruna faz uso da soletração manual, corrigindo sua colega].

Cristal: $\quad$ Este [Cristal aponta para o sofá] e este [aponta para a mesa]. Qual é o nome?

Bruna: $\quad$ M-O-V-E-I-S [Bruna faz uso da soletração manual].

(Fonte: Interação na sessão sobre 'partes da casa' em português). 
Ao apontar para a palavra no quadro e para os objetos expostos na mesa, Cristal oferece scaffolding (WOOD; BRUNER; ROSS, 1976) que leva Bruna a assimilar a palavra 'móveis' em português, e, no momento em que Cristal pergunta o sinal de 'móveis', há o intercâmbio com a Libras, o que proporciona apoio recíproco e instrução entre as duas participantes. Como afirmamos anteriormente, apesar de estudos com o uso de tandem proporem que as línguas devam ser ensinadas separadamente (BRAMMERTS, 2002; VASSALO; TELLES, 2009), percebemos, no exemplo [4], que Bruna usa a Libras para orientar Cristal a como ensinar o vocábulo 'móveis' aos surdos, explicando que ela tem de usar sinais referentes a móveis e o sinal 'diversos' para passar o conceito de 'móveis' em Libras. Esse exemplo nos mostra que, na aula de português, Cristal aprendeu a conceituar 'móveis' em Libras. Tal exemplo corrobora o estudo de Figueiredo e Silva (2016) - que apresenta uma análise sobre as interações na aprendizagem de línguas estrangeiras em contexto de teletandem ${ }^{16}$-, quando relatam que as línguas envolvidas não se separam durante as sessões, e esse processo natural se caracteriza como um aspecto positivo nas interações, pois favorece trocas mútuas entre os participantes, bem como o engajamento deles em atividades de coconstrução do conhecimento (FIGUEIREDO, 2018, 2019; VYGOTSKY, 1998).

Outra estratégia de ensino, usada por Cristal, se dá com a utilização de diferentes símbolos no quadro branco, como a localização das palavras nas frases, bem como palavras que devem ser acrescentadas na frase em português. Essas estratégias podem ser mais bem visualizadas na figura a seguir.

Figura 3 - Uso de símbolos por Cristal: palavras circuladas e setas

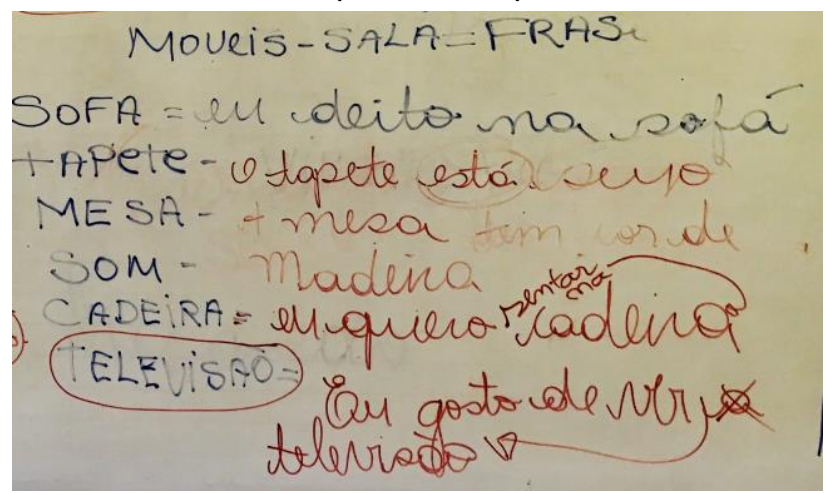

Fonte: Sessão sobre 'partes da casa' em português.

Nessa figura, Cristal escreveu algumas palavras no quadro (sofá, tapete etc.) para que Bruna as usasse na construção de sentenças. Podemos perceber que algumas palavras foram omitidas por Bruna, como "sentar na" e outras acrescentadas desnecessariamente, como "ver $a$ televisão".

\footnotetext{
${ }^{16}$ No teletandem, os parceiros estão em lugares diferentes (tandem a distância), e sua interação é mediada pelo computador e pela internet, por meio de recursos de áudio, vídeo e escrita (BENEDETTI; RODRIGUES, 2010; FIGUEIREDO; SILVA, 2016; VASSALLO; TELLES, 2009).
} 
Cristal corrige as sentenças fazendo uso de símbolos - como setas e riscos -, bem como de pincéis de cores diferentes para chamar a atenção da colega, como pode ser visto na palavra 'televisão', que é circulada com a cor vermelha. Segundo a estudante, ela utilizou a estratégia de uso de diferentes símbolos por tê-la vivenciado e aprendido em seu processo de ensino-aprendizagem de sua língua materna nas escolas em que estudou. Conforme ela nos esclareceu durante a entrevista, ao ser questionada sobre o uso de símbolos, ela relata que os utilizou por acreditar que essa estratégia, por ser visual, seria benéfica à Bruna, a utilizando para mostrar a diferença sintática do português e da Libras, como podemos verificar em seu relato.

[5]

Cristal: $\quad$ Eu usei os símbolos porque queria que a Bruna visse onde a palavra ficava na frase. Eu circulei a palavra também, com cor diferente, para chamar sua atenção para as palavras que não haviam sido colocadas na frase [Cristal refere-se à palavra 'televisão' que foi por ela circulada, visto que Bruna não a escreveu na frase produzida]. Eu também quis mostrar para a Bruna que, em português e em Libras, a organização da frase é diferente [referindo-se às setas que usou]. Por exemplo, na Libras fica tudo junto no espaço, né? [Referindo-se ao fato de que, na Libras, os conceitos de 'sentar' e 'cadeira' encontram-se imbricados em um mesmo sinal]. Mas, no português, não. Então, eu sei que português é ensinado diferente para surdos [referindo-se ao uso de estratégias visuais]. Desse modo, usar desse jeito, circulando a palavra, ou fazendo seta, ou riscar a palavra, também pode ser usado com os surdos. É o jeito que a gente vai ensinar que é diferente, né? Assim, com alunos ouvintes, os professores vão falando e escrevendo junto. Mas com surdo, não. Precisa escrever primeiro e mostrar depois, por exemplo.

(Fonte: Entrevista após a sessão sobre 'partes da casa' em português).

A estratégia de uso de símbolos no ensino de uma L2 para surdos também foi identificada nos estudos de Figueiredo e Oliveira-Silva (2016) e de Oliveira-Silva (2017). Segundo os autores, fazer uso de símbolos e escrever as palavras no quadro são estratégias eficazes no processo de ensino de uma língua de modalidade escrita para surdos, pois tais recursos viabilizam o suporte visual necessário para eles, facilitando, assim, a compreensão das explicações sobre o conteúdo ministrado.

Uma estratégia ineficaz usada pelos participantes ouvintes para ensinar português escrito aos parceiros surdos foi o uso de gestos. Segundo Leland e Viotti (2011), a diferença entre gestos e fala é evidente, mas isso não ocorre com tanta clareza nas línguas de sinais, já que os elementos linguísticos dessas línguas também são produzidos através das mãos, corpo e expressões faciais. Quando se trata da interação com o uso de gestos e mímicas, a comunicação pode tornar-se desafiadora, provocando confusão. Conforme afirmam Knapp e Hall (2002), os gestos são culturalmente construídos e, nas línguas sinalizadas, podem obter outros significados.

No exemplo [6], a seguir, podemos perceber o uso de gestos e mímicas como estratégias utilizadas por Saskya durante a segunda sessão, no momento de ensino de português. Nesse dia, o par trabalhava a temática 'profissões'. Saskya escreve no quadro branco o nome de uma série de profissões e simula, por meio de gestos e mímicas, as características de cada profissional. 
Vejamos, na figura 4, a lista dessas profissões para melhor compreendermos essa estratégia.

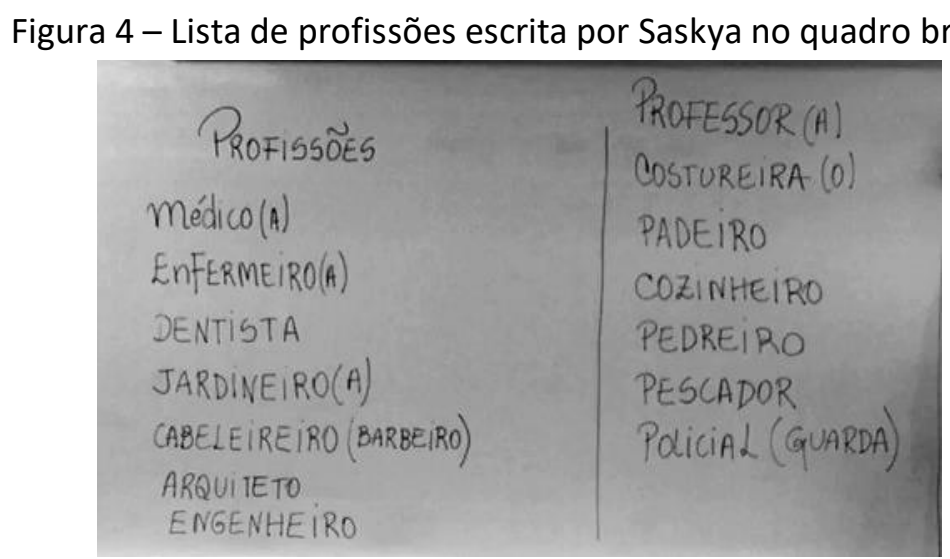

Fonte: Aula sobre 'profissões' em português.

Após escrever os nomes no quadro, Saskya pediu a Felipe que fizesse os sinais em Libras para cada profissão apresentada. No entanto, quando ela começa a explicar a função de cada profissional, utiliza gestos para esse fim. Podemos observar, na interação a seguir, que Felipe ficou confuso quando Saskya tentou explicar a ele que o jardineiro é o profissional que cuida das flores. A confusão surgiu devido ao fato de Saskya não saber construir a sentença 'pegar uma flor' em Libras e de Felipe não conhecer a palavra 'jardineiro' em português. Por não conhecer a estrutura na Libras, Saskya apoia-se na estratégia de fazer gestos para tentar se comunicar com o seu colega. Ela decide, então, fazer o gesto de alguém pegando uma flor no chão e a cheirando, mas, ao fazê-lo, ela usa o formato da mão fechada, que também pode representar a configuração usada para a letra 's' no alfabeto manual, conforme é ilustrado na figura 5.

Figura 5 - Configuração de mão usada por Saskya no exemplo [6]

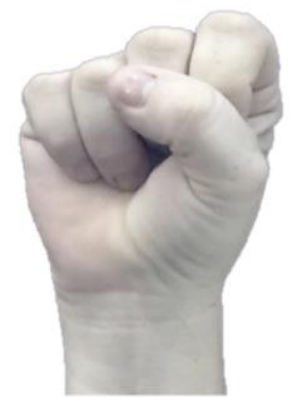

Fonte: Baralho de configuração de mãos produzido pelo CAS - $\mathrm{GO}^{17}$.

Ao usar essa configuração de mão, Saskya deixou Felipe confuso, visto que ela pode representar, em Libras, microfone, cantor, palestrante etc., como pode ser verificado na seguinte interação.

\footnotetext{
${ }^{17}$ Disponível em: http://cascursolibrasgoias.blogspot.com.br. Acesso em: 17 abr. 2020.
} 
[6]

Saskya: Qual é o sinal? [Saskya aponta para a palavra 'jardineiro', escrita no quadro].

Felipe: $\quad$ Não conheço essa palavra [Felipe faz expressão facial de dúvida].

Saskya: Ele [Saskya aponta para a palavra 'jardineiro' no quadro] trabalha com... [Saskya simula uma pessoa pegando uma flor no chão e trazendo ao nariz para cheirar].

Felipe: $\quad 0$ que é isso? [Felipe repete os gestos produzidos por Saskya].

Saskya: Igual, no chão tem muito, e as pessoas pegam e cheiram [Saskya repete o gesto anterior].

Felipe Microfone? Cantor? Palestrante? Não entendi.

(Fonte: Sessão sobre 'profissões' em português).

Os gestos feitos por Saskya não foram compreendidos por Felipe, visto que ela usou uma representação imagética que, na Libras, não significa 'pegar uma flor', mas, sim, uma configuração de mão que resultou em outros significados. Devido a isso, Felipe pensou que ela estava se referindo a 'microfone', 'cantor' ou 'palestrante', já que essa configuração de mão pode ser usada para se referir a esses conceitos. Por razões didáticas, apresentamos, na figura a seguir, a configuração de mão adequada que pode ser usada para se referir a alguém pegando na haste de uma flor no chão e levando-a ao nariz para sentir o perfume.

Figura 6 - Possível configuração de mão para representar, em Libras, alguém pegando uma flor

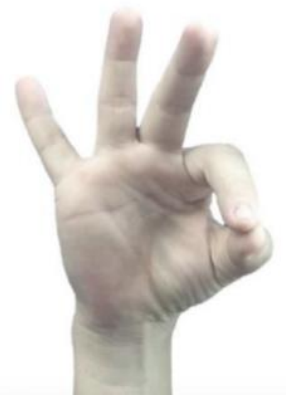

Fonte: Baralho de configuração de mãos produzido pelo CAS - $\mathrm{GO}^{18}$.

Como podemos verificar, o uso de gestos como meio de interação comunicativa em aulas de línguas para alunos surdos pode se tornar uma estratégia ineficaz, dificultando-lhes o processo de ensino-aprendizagem. Estudos como os de Figueiredo e Oliveira-Silva (2016) e de Oliveira-Silva (2017) apresentam resultados semelhantes. Os autores perceberam que alguns gestos produzidos pela professora nas interações com os surdos não eram eficazes, visto que tinham outro significado em Libras, expressando, portanto, algo diferente do que ela pretendia dizer (KNAPP; HALL, 2002).

Outra contribuição da aprendizagem em tandem face a face se dá pela compreensão de que as trocas entre os participantes não se limitam apenas às linguísticas, pois possibilitam também trocas culturais. Assim, "em cada diálogo tandem, as circunstâncias da vida, as experiências e os conhecimentos do parceiro transformam-se no tema quase natural da conversa" (BRAMMERTS, 2002, p. 17).

\footnotetext{
${ }^{18}$ Disponível em: http://cascursolibrasgoias.blogspot.com.br. Acesso em: 17 abr. 2020.
} 
A figura 7 é usada por Cristal para ensinar à Bruna 'partes da casa' em português. Entre os vocábulos trabalhados, está a palavra 'Som'. Para tanto, Cristal apresenta a imagem de um aparelho de som, como ilustrado a seguir.

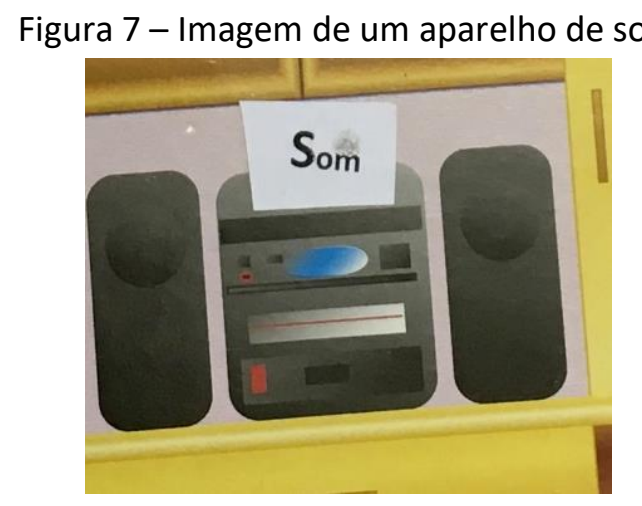

Fonte: Sessão sobre 'partes da casa' em português.

Por meio dessa figura, Cristal pergunta à Bruna, sua colega surda, se ela gosta de ouvir música. Bruna escreve, no quadro branco, que não gosta de ouvir música, mas, sim, sentir as vibrações da música em seu corpo, conforme ilustrado a seguir.

Figura 8- Resposta de Bruna a Cristal sobre gostar de música

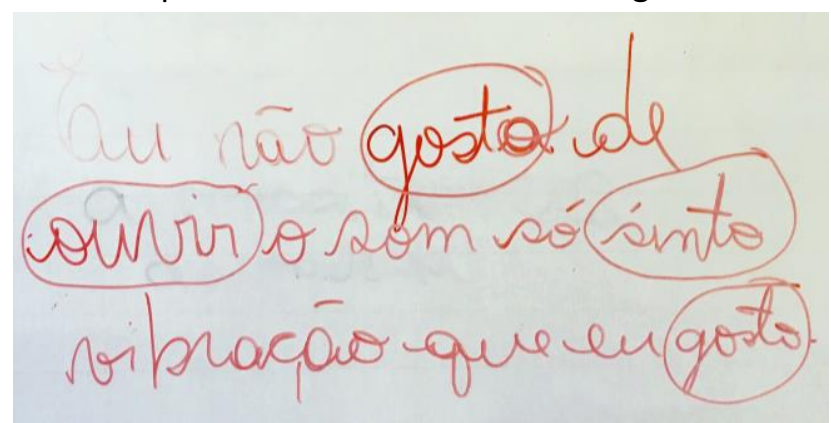

Fonte: Aula sobre 'partes da casa' em português.

Alguns autores ponderam que a comunidade surda tem uma cultura peculiar, desenvolvida por meio de suas percepções visuais de mundo e de sua língua sinalizada que constituem suas identidades (SKLIAR, 2015; STROBEL, 2009). As experiências sonoras da cultura ouvinte são apreciadas, por alguns surdos, por meio da vibração do som, que é sentida por seus corpos, possibilitando, assim, seu contato com a música (HAGUIARACERVELLINI, 2003). Esse fato, como vimos, pôde ser esclarecido à Cristal por meio do depoimento escrito por Bruna no quadro branco, pois Cristal compreendeu que a música é apreciada por alguns surdos pela percepção visual e pela sensação provocada pela vibração em seu corpo e não por percepções sonoras. 
As percepções dos alunos surdos acerca de sua participação nas sessões de tandem face a face

Durante as entrevistas, os participantes surdos elencaram alguns aspectos positivos e negativos sobre a participação nas sessões de tandem face a face, como é abordado a seguir.

Pontos positivos das interações em tandem face a face, apresentados pelos participantes surdos

A coconstrução produzida pelos participantes nas interações durante as sessões de tandem face a face (BRAMMERTS, 2002) resultou em algumas estratégias eficazes no processo de ensino-aprendizagem de português escrito dos estudantes surdos. Felipe, por exemplo, relata que, por meio das trocas realizadas nas interações, ele pôde compartilhar conhecimentos e ressignificar conceitos já estabelecidos: o conceito de 'cirurgião' foi a ele esclarecido. Felipe ressalta como positivo o fato de ter tido acesso a novas palavras na língua portuguesa com o uso do suporte imagético. Segundo ele, o uso de imagens por Saskya e a interação com a colega possibilitaram-Ihe a ampliação lexical, como, por exemplo, o conceito de 'médico', que o levou à palavra 'cirurgia' e, posteriormente, a 'cirurgião'.

\section{[7]}

Pesquisador: O que achou de aprender português com sua colega ouvinte por meio do tandem?

Felipe: $\quad$ Muito bom, porque eu perguntava sempre o nome de alguma coisa que estava na imagem que Saskya me mostrava, e ela escrevia no quadro, também usava Libras para me explicar. Eu aprendi muito com ela. Aprendi o nome de algumas profissões, também aprendi sobre partes da casa, foi muito legal, mas ela também me explicava sempre alguma coisa a mais. Por exemplo, na aula de profissões, ela trouxe a imagem de um médico. Daí, ela me explicou o que significava a palavra 'cirurgião'. Eu só conhecia médico, entendeu?

(Fonte: Entrevista após a segunda sessão).

Para Bruna, a aprendizagem colaborativa em contexto de tandem face a face também possibilitou-lhe prover, à colega ouvinte, esclarecimentos acerca do uso da oralização por parte do ouvinte na busca de uma interação com uma pessoa surda. Segundo ela, os ouvintes tendem a utilizar a oralização quando desconhecem algum sinal (BOTELHO, 2013), como é ilustrado no exemplo [8].

[8]

Pesquisador: Qual a sua opinião acerca da produção sinalizada da sua colega nos momentos de interação?

Bruna: $\quad$ Eu percebi que ela tinha muita dificuldade em sinalizar. Às vezes, eu não entendia o que ela queria explicar porque ela oralizava muito junto com os sinais, e isso me confundia bastante. Depois que eu expliquei para ela não falar junto com os sinais, foi ficando melhor.

(Fonte: Entrevista após a primeira sessão).

Outra característica positiva, apontada pelos participantes, é a oportunidade que têm de esclarecer como o indivíduo surdo acessa informações acerca de artefatos culturais 
produzidos por ouvintes. No exemplo a seguir, Bruna menciona que pôde esclarecer, para Cristal, sua parceira ouvinte, a relação que os surdos têm com a música.

[9]

Bruna: Eu não fiquei chateada com a pergunta da Cristal [se eu gosto de ouvir música]. Acho que ela estava nervosa porque era nossa primeira sessão [risos]. Sempre que conheço um ouvinte e faço amizade nas festas, me perguntam isso porque me veem com meus amigos surdos dançando e nos divertindo. Os ouvintes pensam que nós surdos não gostamos de música porque não ouvimos. Bem, tem surdos que não gostam de música, mas tem surdos que gostam sim. Eu gosto. Sempre gosto de dançar músicas mais animadas, com batidas mais fortes, porque aí a vibração no meu corpo é melhor. Gosto também de sertanejo, dançar juntinho [risos]. Os surdos e também os ouvintes que sabem Libras precisam mostrar para as outras pessoas que nós não ouvimos a música, mas percebemos o ritmo com a visão das pessoas dançando e também sentimos em nosso corpo as batidas.

(Fonte: Entrevista com Bruna sobre as trocas vivenciadas na primeira sessão).

Como afirma Little (2002), essa capacidade de reformular e compartilhar conhecimentos é propiciada a partir do princípio da reciprocidade, a qual é experimentada nos momentos de oferta de feedbacks entre os parceiros. No que tange à competência intercultural, apontada por Felipe e Bruna, Woodin (2002) nos esclarece que, por ter um formato educacional, a aprendizagem de línguas em tandem oferece um ambiente ímpar, confortável aos participantes, para expressarem suas percepções sobre comportamento, crenças e costumes diferentes entre eles.

Como podemos perceber, os relatos dos participantes surdos corroboram os estudos desenvolvidos sobre a colaboração no ensino de línguas em contexto de tandem que afirmam que, nessa abordagem, os indivíduos podem adquirir mais do que conhecimento linguístico; ou seja, podem, também, aprender sobre a cultura do outro, o que desenvolve a sua competência intercultural, promovida pela troca de informações viabilizadas na parceria desenvolvida entre eles (BENEDETTI; RODRIGUES, 2010; BRAMMERTS, 2002; FIGUEIREDO; SILVA, 2016; LITTLE, 2002; SILVA, 2012; WOODIN, 2002).

Os participantes surdos também enfatizaram a importância do uso de recursos imagéticos pelos parceiros ouvintes para facilitar-Ihes a aprendizagem do português. Bruna, por exemplo, ressalta que Cristal usou imagens e objetos para ensinar a ela novas palavras em português.

[10]

Pesquisador: O que você achou de aprender português com sua colega ouvinte através do tandem? Bruna:

Foi muito bom! Eu gostei muito. A Cristal usou brinquedos de boneca [referindo-se às miniaturas dos móveis da sala]. Isso me fez aprender novas palavras em português porque ela me mostrava o brinquedo e eu associava com as palavras que ela ensinava. Ela também sempre tinha calma para me explicar quando eu não entendia alguma palavra, ou alguma coisa. Eu acho que assim, sempre só nós duas, foi muito bom, porque eu perguntava, e ela sempre respondia com tranquilidade, sem se distrair com outras pessoas, igual acontece nas aulas de português no curso. Assim, por exemplo, como só tínhamos nós duas, então eu ficava mais à vontade para questionar ou também comentar alguma coisa que ela explicava e eu mostrava como era o sinal em Libras. É bem melhor aprender assim, eu acho.

(Fonte: Entrevista após a primeira sessão de tandem face a face). 
Vimos que as interações possibilitaram, aos participantes surdos, ampliar conhecimento linguístico sobre o português - aprendizagem de novas palavras, ampliação lexical, construção de estruturas frasais -, bem como esclarecer algumas questões culturais dos surdos, como, por exemplo, como percebem a música, a forma como sofreram para aprender português ao serem oralizados (cf. exemplo [12]), o uso dos gestos etc. Também puderam se expressar sobre o uso de estratégias que contemplem positivamente o ensino de português para surdos: uso de imagens, uso de palavras escritas no quadro com pincéis de diferentes cores, o uso de símbolos e o uso de objetos.

Apesar dos pontos positivos apontados, os participantes surdos também elencaram aspectos negativos sobre a aprendizagem em tandem, conforme podemos observar a seguir.

\section{Pontos negativos das interações em tandem apresentados pelos participantes surdos}

Os participantes surdos mencionaram alguns aspectos negativos da aprendizagem em tandem, tais como: a dificuldade de entender a colega quando ela desconhecia algum sinal ou alguma palavra; uso de estratégias que não favoreceram a interação significativa entre os pares, como, por exemplo, o uso do português sinalizado, da oralização, da oralização com o uso de sinais (bimodalismo) e o uso de gestos.

Vejamos, no exemplo a seguir, o momento em que Bruna aponta que o uso da estratégia de oralizar pode se tornar um fator que dificulta a interação e a compreensão.

[11]

Bruna: Às vezes, os ouvintes acham que, ao oralizar, vão se comunicar bem comigo, mas não é verdade. Eu não sei leitura labial e só entendo uma palavra vez ou outra [...]. Muitas vezes, eu acho que o ouvinte falou uma palavra, mas eu entendi outra. Por exemplo, teve um momento em que a Cristal oralizou 'entendeu' e eu entendi 'perdeu', porque achei que ela estava me perguntando com quantos anos eu tinha perdido minha audição [risos].

(Fonte: Entrevista após a primeira sessão).

Na entrevista realizada após a sessão sobre o ensino de 'profissões' em português, Felipe também demonstrou o desconforto que teve quando Saskya usava oralização junto com sinais (bimodalismo), bem como português sinalizado para se comunicar com ele. Seu relato ilustra também as afirmações de Lodi, Bortoloti e Cavalmoretti (2004) de que muitos surdos adultos passaram por um processo de escolarização, pautado na oralização, que não Ihe favorecia a aprendizagem, como é verificado no exemplo [12].

[12]

Felipe: Eu achei desconfortável quando Saskya oralizava comigo. Eu não entendi bem. Achei que ela estava dizendo 'bola' ou 'babá'. Eu não vejo a diferença no movimento dos lábios direito. É tudo muito parecido. Eu não sei leitura labial. Eu fiz terapia desde os meus oito anos até os quatorze, mas nunca consegui desenvolver bem a fala oral. Eu já sofri muito tentando aprender a falar português e nunca me senti bem tentando oralizar. Na escola em que eu estudei quando criança, as professoras me forçavam a falar português oralmente. Às vezes, elas me proibiam de sinalizar para reforçar a prática oral. Eu detestava isso. Nunca me identifiquei com a fala oral. Me sentia envergonhado. Já sofri bullying porque a minha voz não é natural igual à voz dos ouvintes. Quando os ouvintes fazem sinais e 
oralizam junto com a sinalização, igual português sinalizado, eu fico muito confuso. Não entendo o movimento da boca. Fico perdido, não sei se olho para a boca, ou para os sinais. Eu não falei nada para Saskya porque ela estava se esforçando em me ajudar a aprender português e achei que ela ficaria chateada se eu a cortasse e explicasse isso. Então, eu decidi ficar calado. Depois, ela aprende, no Letras: Libras, que português sinalizado não é bom, confunde os surdos.

(Fonte: Entrevista com Felipe após a sessão sobre 'profissões').

Os relatos de Bruna e Felipe evidenciam que estratégias de ensino, pautadas na metodologia oralista, ainda persistem nas interações entre surdos e ouvintes e, conforme aponta Skliar (2015), esse fato pode causar-lhes uma série de desconfortos e dificuldades nas interações. Felipe ainda ressalta que preferiu silenciar-se a esclarecer para Bruna que a estratégia de ensino adotada por ela para ensinar português escrito era ineficaz para os surdos. Percebemos que não somente o contexto oralizado de ensino predomina, mas também a supremacia de estratégias de ensino pertencentes à língua e ao contexto dos ouvintes. O professor ouvinte ainda não consegue com eficácia deslocar-se de seu lugar de ouvinte para o lugar do aprendiz surdo. E o aluno surdo, no caso de Felipe, por já ter enfrentado situações de constrangimento, opta por calar-se. Tal fato revela o quanto a relação ouvinte-surdo ainda precisa ser discutida, pois reflexões acerca dessa relação, em contexto de tandem ou não, podem levar surdos e ouvintes a colaborativamente ampliar e aprimorar o processo de ensino-aprendizagem de línguas.

Felipe também argumenta que o uso de gestos pode se configurar como uma estratégia não eficaz no ensino de português para surdos. Segundo ele, ao usar gestos, os ouvintes podem ter a falsa impressão de que foram bem-sucedidos no processo comunicativo com os surdos. No exemplo a seguir, Felipe menciona o fato de Saskya ter feito um gesto para expressar a palavra 'jardineiro', que fez com que ele compreendesse algo totalmente diferente.

[13]

Felipe: Ela usou o formato da mão errada. Na Libras, usamos a configuração de mão assim [Felipe reproduz a configuração de mão ilustrada na figura 6]. A configuração de mão [Felipe reproduz a configuração de mão usada por Saskya, ilustrada na figura 5] parece, para nós surdos, outras coisas, como, por exemplo, microfone, ou cantor, ou um palestrante falando, também pode ser sorvete... entende?

(Fonte: Entrevista com Felipe após a sessão sobre 'profissões').

Pelos relatos dos participantes, podemos perceber que os pontos positivos, em relação à participação deles nas sessões de tandem para o processo de ensino-aprendizagem de português, foram mais recorrentes do que os negativos. Os participantes surdos puderam experienciar os benefícios que a colaboração trouxe para sua aprendizagem e apontaram, inclusive, a contribuição que essas interações trouxeram para a sua formação docente.

\section{Considerações finais}

Os dados nos evidenciam que os participantes deste estudo, surdos e ouvintes, lançaram mão de diferentes scaffoldings durante as suas interações nas sessões de tandem 
face a face. Eles faziam perguntas aos seus pares para esclarecer dúvidas e para levá-los à coconstrução significativa do assunto que estavam abordando. Quando não se faziam compreendidos, usavam várias estratégias para se expressarem e para auxiliar a aprendizagem de seus colegas. Algumas dessas estratégias não foram eficazes, como o uso de gestos e a oralização, por parte das participantes ouvintes. Entretanto, vale ressaltar que algumas estratégias ineficazes se converteram em eficazes - a oralização, por exemplo, foi substituída pela escrita, por parte de Cristal (ver exemplo 3 e figura 1) - por conta das negociações colaborativas proporcionadas durante o processo de ensino-aprendizagem em tandem, abordado neste estudo. Também verificamos que a soletração manual, acrescida de scaffoldings e recursos visuais, converteu-se em uma estratégia eficaz de auxílio ao processo de ensino-aprendizagem de português escrito para os surdos.

Para ensinar português escrito aos parceiros surdos, as estudantes ouvintes fizeram uso de algumas estratégias que foram consideradas, por eles, como eficazes e não eficazes. Entre as eficazes, estão o uso de imagens, a escrita no quadro branco, o uso de pincéis de cores diferentes, o uso de símbolos, o uso da soletração manual, acompanhado por scaffoldings mediados pela língua de sinais, e o uso de objetos. Entre as não eficazes, estão o uso da oralização, o uso da oralização com sinais (bimodalismo), o uso exclusivo da soletração manual e o uso de gestos que não levam à compreensão.

Percebemos, portanto, que o uso de imagens, desenhos, traços ou outros símbolos escritos, ou seja, de recursos visuais, atrelado ao processo de ensino de português escrito, é uma estratégia eficiente a ser usada com alunos surdos. Conforme afirma Goés (1999), o uso de palavras acompanhadas de imagens pode favorecer, aos surdos, a construção de sentidos no processo de ensino-aprendizagem do português escrito.

Por ter dado voz aos alunos surdos para expressar suas percepções acerca de sua participação em sessões de tandem face a face, podemos afirmar que a interação nessas sessões possibilitou-Ihes crescimento linguístico, cultural e colaborou também para seu crescimento profissional, visto que serão futuros professores e puderam, nas interações, vivenciar o papel de alguém que foi auxiliado pelo outro a aprender. Destacamos também que, por meio das interações com seus pares, os participantes surdos se sentiram confortáveis e estimulados a se expressarem sobre o que gostaram e sobre o que não gostaram em relação ao seu processo de aprendizagem do português escrito.

A aprendizagem em tandem se mostrou profícua também quando as línguas envolvidas são de modalidade diferente - oral (português) e sinalizada (Libras). Percebemos que as interações e as dúvidas de seus parceiros fizeram com que os participantes tivessem atitudes colaborativas um com o outro, pois era natural a necessidade de buscarem alternativas para serem bem-sucedidos na tarefa de auxiliar o seu par na aprendizagem da língua-alvo.

Convidamos, portanto, os professores surdos e ouvintes que trabalham com Português para surdos a possibilitar a seus alunos ter um papel mais ativo e autônomo em seu processo de aprendizagem - como foi vivenciado nas interações em tandem evidenciadas 
neste estudo -, para que, juntos, possam se desenvolver em aspectos linguísticos, culturais, profissionais e pessoais e, com isso, se tornarem cidadãos mais colaborativos e abertos às diversidades.

\section{Referências}

ALMEIDA, D. L. de; LACERDA, C. B. F. de. Português como segunda língua: a escrita de surdos em aprendizagem coletiva. Trabalho em Linguística Aplicada, v. 58, n. 2, p. 899-917, 2019. https://doi.org/10.1590/010318138653579436691

ANASTASIOU, L. G. C.; ALVES, L. P. (org). Processos de ensinagem na universidade: pressupostos e estratégias de trabalho em sala de aula. 3. ed. Joinvile: UNIVILLE, 2004.

BENEDETTI, A. M.; RODRIGUES, D. G. Choques linguístico-culturais e o desenvolvimento da competência intercultural em teletandem. In: BENEDETTI, A. M.; CONSOLO, D. A.; VIEIRAABRAHÃO, M. H. (org.). Pesquisas em ensino e aprendizagem no teletandem Brasil: línguas estrangeiras para todos. Campinas: Pontes, 2010. p. 89-104.

BOGDAN, R.; BIKLEN, S. Investigação qualitativa em educação: uma introdução à teoria e aos métodos. Porto: Porto Editora, 1994.

BORDENAVE, J. D.; PEREIRA, A. M. Estratégias de ensino-aprendizagem. Petrópolis: Vozes, 1998.

BOTELHO, P. Linguagem e letramento na educação de surdos: ideologias e práticas pedagógicas. Belo Horizonte: Autêntica Editora, 2013.

BRAMMERTS, $\mathrm{H}$. Aprendizagem autónoma de línguas em tandem: desenvolvimento de um conceito. In: DELILLE, K. H.; CHICHORRO, A. (org.). Aprendizagem autónoma de línguas em tandem. Lisboa: Colibri, 2002. p. 15-25.

BRUFFEE, K. A. Collaborative learning: Higher education, interdependence, and the authority of knowledge. London: The Johns Hopkins University Press, 1999.

CALIXTO, H. R. S.; RIBEIRO, A. E. A.; RIBEIRO, A. A. Ensino de língua portuguesa escrita na educação bilíngue de surdos: questões a partir de narrativas de professores da Baixada Fluminense. Revista Brasileira de Estudos Pedagógicos, Brasília, v. 100, n. 256, p. 578-593, 2019. http://dx.doi.org/10.24109/2176-6681.rbep.100i256.4021

CAPOVILLA, F. C.; RAPHAEL, W. D.; MAURÍCIO, A. C. L. DEIT-LIBRAS - Dicionário Enciclopédico Ilustrado Trilíngue. Volume 1. 3. ed. São Paulo, SP.: Edusp, 2013.

CICCONE, M. M. C. Comunicação total: introdução, estratégia, a pessoa surda. Rio de Janeiro: Editora Cultura Médica, 1990.

FELIPE, T. Política públicas para inserção da Libras na educação de surdos. Revista Informativo Científico Espaço - INES, Rio de Janeiro, n. 25/26, p. 33-47, 2006.

FERNANDES, E. Linguagem e surdez. Porto Alegre: Artmed, 2003.

FERNANDES, S. F. Educação bilíngue para surdos: identidades, diferenças, contradições e mistérios. 2003. 202 f. Tese (Doutorado em Letras) - Setor de Ciências Humanas, Letras e Artes, Universidade Federal do Paraná, Curitiba, 2003. 
FIGUEIREDO, F. J. Q. de. Aprendendo com os erros: uma perspectiva comunicativa de ensino de línguas. 3. ed. rev. ampl. Goiânia: Editora UFG, 2015.

FIGUEIREDO, F. J. Q. de. A aprendizagem colaborativa de línguas: considerações conceituais e aplicações em distintos contextos. In: FIGUEIREDO, F. J. Q. de. (org.). 2. ed. rev. ampl. A aprendizagem colaborativa de línguas. Goiânia: Editora UFG, 2018. p. 13-57.

FIGUEIREDO, F. J. Q. de. Vygotsky - a interação no ensino-aprendizagem de línguas. São Paulo: Parábola, 2019.

FIGUEIREDO, F. J. Q. de; OLIVEIRA, Q. M. de. A deaf and a hearing student learning Portuguese and Libras in a tandem context. Revista do GEL, v. 15, p. 58-72, 2019. http://dx.doi.org/10.21165/gel.v15i3.2389

FIGUEIREDO, F. J. Q. de.; OLIVEIRA-SILVA, C. M. de. Uma análise da eficácia das estratégias de ensino utilizadas por uma professora ministrando aulas de inglês instrumental para alunos surdos em uma sala de aula inclusiva na universidade. In: FIGUEIREDO, F. J. Q. de.; SIMÕES, D. (org.). Linguística Aplicada, prática de ensino e aprendizagem de línguas. Campinas: Pontes, 2016. p. 235-282.

FIGUEIREDO, F. J. Q. de.; OSÓRIO, P.; MIRANDA, F. Contribuições da linguística aplicada para o ensino e a aprendizagem de português como língua estrangeira. In: FERRREIRA, M. C. F. D.; REICHMANN, C. L.; ROMERO, T. R. S. (org.). Construções identitárias de professores de línguas. Campinas, SP.: Pontes, 2016. p. 103-120.

FIGUEIREDO, F. J. Q. de.; SILVA, S. V. da. Do tandem ao teletandem: estudos sobre o uso da colaboração na aprendizagem de línguas em contexto virtual. In: JORDÃO, C. M. (org.). A linguística aplicada no Brasil: rumos e passagens. Campinas: Pontes, 2016. p. 309-336.

GARCIA, D. N. M. O que os pares de Teletandem (não) negociam: práticas para um novo contexto online interativo para o ensino/aprendizagem de línguas estrangeiras no século XXI. São Paulo: Ed. Unesp, 2013. p. 11-29.

GÓES, M. C. R. Linguagem, surdez e educação. 2. ed. Campinas: Editora Autores Associados, 1999.

GOLDFELD, M. A criança surda: linguagem e cognição numa perspectiva sóciointeracionista. São Paulo: Plexus, 1997.

HAGUIARA-CERVELLINI, N. A musicalidade do surdo: representação e estigma. 2. ed. São Paulo: Plexus, 2003.

KIM, T.; LIVESCU, K.; SHAKHNAROVICH, G. American sign language fingerspelling recognition with phonological feature-based tandem models. 2012. IEEE Workshop on Spoken Language Technology, SLT 2012 - Proceedings. http://dx.doi.org/10.1109/SLT.2012.6424208.

KNAPP, M. L.; HALL, J. A. Nonverbal communication in human interaction. 5. ed. Boston, MA.: Wadsworth Thompson Learning, 2002.

LACERDA, C. B. F.; LODI, A. C. B. A inclusão escolar bilíngue de alunos surdos: princípios, breve histórico e perspectivas. In: LACERDA, C. B. F.; LODI, A. C. B. (org.). Uma escola duas línguas: letramento em língua portuguesa e língua de sinais nas etapas iniciais de escolarização. Porto Alegre: Mediação, 2009. p. 11-32. 
LELAND, M.; VIOTTI, E. Língua e gesto em línguas sinalizadas. Veredas online, v. 1, p. 289304, 2011.LIMA, N. M. F. Inclusão escolar de surdos: o dito e o feito. In: LODI, A. C. B.; MÉLO, A. D. B.; FERNANDES, E. (org.). Letramento, bilinguismo e educação de surdos. Porto Alegre: Editora Mediação, 2012. p. 303-332.

LITTLE, D. A aprendizagem de línguas em tandem e a autonomia do aprendente. In: CHICHORRO, A.; DELILLE, K. H. (org.). Aprendizagem autónoma de línguas em tandem. Lisboa: Edições Colibri, 2002. p. 27-35.

LODI, A. C. B.; BORTOLOTTI, E. C.; CAVALMORETI, M. J. Z. Letramentos de surdos: práticas sociais de linguagem entre duas línguas/culturas. Bakhtiniana, Revista de estudos do Discurso, São Paulo, v. 9, n. 2, p. 131-149, 2004.

NUNAN, D. (Ed.). Collaborative language learning and teaching. Cambridge: Cambridge University Press, 1992.

OLIVEIRA-SILVA, C. M. A aprendizagem colaborativa de inglês instrumental por alunos surdos: um estudo com alunos do curso de Letras: Libras da UFG. 2017. 262 f. Tese (Doutorado em Letras e Linguística) - Faculdade de Letras, Universidade Federal de Goiás, Goiânia, 2017.

OLIVEIRA, Q. M. de. A aprendizagem de libras e de português em contexto de tandem: um estudo com alunos do curso de Letras: Libras da UFG. 2017. 127 f. Dissertação (Mestrado em Letras e Linguística) - Faculdade de Letras, Universidade Federal de Goiás, Goiânia, 2017.

OLIVEIRA, Q. M. de.; FIGUEIREDO, F. J. Q. de. Educação dos surdos no Brasil: um percurso histórico e novas perspectivas. Revista Sinalizar, v. 2, n. 2, p. 173-196, 2017a. https://doi.org/10.5216/rs.v2i2.50544

OLIVEIRA, Q. M. de.; FIGUEIREDO, F. J. Q. de. Aprendizagem de libras e português em contexto de tandem: um estudo realizado com uma aluna surda e uma ouvinte da Universidade Federal do Tocantins. Caderno Seminal Digital, v. 28, p. 1-24, 2017b. http://dx.doi.org/10.12957/cadsem.2017.28833

OXFORD, R. L. Cooperative learning, collaborative learning, and interaction: Three communicative strands in the language classroom. The Modern Language Journal, v. 81, n. 4, p. 443-456, 1997. https://doi.org/10.1111/j.1540-4781.1997.tb05510.x

PEREIRA, M. C. C. Papel da língua de sinais na aquisição da escrita por estudantes surdos. In: LODI, A. C. B. et al. (org.). Letramento e minorias. 7. ed. Porto Alegre: Editora Mediação, 2014. p. 45-52.

QUADROS, R. M. Educação de surdos: a aquisição da linguagem. Porto Alegre: Artmed, 1997.

QUADROS, R. M. Língua de herança: língua brasileira de sinais. Porto Alegre: Penso, 2017.

QUADROS, R. M.; KARNOPP, L. B. Língua de sinais brasileira: estudos linguísticos. Porto Alegre: Artmed, 2004. QUADROS, R. M.; FINGER, I. Teorias de aquisição da linguagem. Florianópolis: Ed. UFSC, 2008.

RABELO, A. S. Português Sinalizado: Comunicação Total. v. 1. Goiânia: Editora UCG, 1992.

RIBEIRO, V. P. Ensino de língua portuguesa para surdos: percepções de professores sobre adaptação curricular em escolas inclusivas. Curitiba: Editora Prismas, 2013. 
SILVA, M. P. M. A construção de sentidos na escrita do aluno surdo. São Paulo: Plexus Editora, 2001.

SILVA, S. V. O processo ensino-aprendizagem de línguas em teletandem: um estudo na área de Turismo. 2012. 293 f. Tese (Doutorado em Letras e Linguística) - Faculdade de Letras, Universidade Federal de Goiás, Goiânia, 2012.

SKLIAR, C. A surdez: um olhar sobre as diferenças. Porto Alegre: Editora Mediação, 2015.

SOUZA, R. A. Telecolaboração e divergência em uma experiência de aprendizagem de português e inglês como línguas estrangeiras. Revista Brasileira de Linguística Aplicada, v. 3, n. 2, p. 73-96, 2003. https://doi.org/10.1590/S1984-63982003000200004

SOUZA, R. A. Telecolaboração na aprendizagem de línguas estrangeiras: um estudo sobre o regime de tandem. In: FIGUEIREDO, F. J. Q. (org.). A aprendizagem colaborativa de línguas. Goiânia: Editora UFG, 2006. p. 255-276.

STROBEL, K. As imagens do outro sobre a cultura surda. 2. ed. Florianópolis: Editora UFSC, 2009. p. 31-37.

SWAIN, M. The output hypothesis and beyond: Mediating acquisition through collaborative dialogue. In: LANTOLF, J. P. (ed.). Sociocultural theory and second language learning. Hong Kong: Oxford University Press, 2000. p. 97-114.

VASSALLO, M. L; TELLES, A. J. Ensino e aprendizagem de línguas em Tandem: princípios teóricos e perspectivas de pesquisa. In: TELLES, A. J. (org.). Teletandem: um contexto virtual, autônomo e colaborativo para aprendizagem de línguas estrangeiras no século XXI. Campinas: Pontes, 2009. p. 17-28.

VYGOTSKY, L. S. A formação social da mente: o desenvolvimento dos processos psicológicos superiores. São Paulo: Martins Pontes, 1998.

WEBSTER, N. Webster's encyclopedic unabridged dictionary of the English language. New York: Gramercy Books, 1989.

WOOD, D.; BRUNER, J. S.; ROSS, G. The role of tutoring in problem solving. Journal of Child Psychology and Psychiatry, v. 17, p. 89-100, 1976. https://doi.org/10.1111/j.14697610.1976.tb00381.x

WOODIN, J. Promover a competência intercultural na aprendizagem em tandem. In: CHICHORRO, A.; DELILLE, K. H. (org.). Aprendizagem autónoma de línguas em tandem. Lisboa: Edições Colibri, 2002. p. 61-66.

Recebido em: 18/04/2020.

Aceito em: 11/06/2020. 